\title{
Migration Issues at the Present Time: Experience and Prospects
}

\author{
Marina A. Yuskova and Igor N. Potemkin* \\ Russian Federal Migration Service of the Krasnoyarsk Kray \\ Krasnoyarsk, 660000, Russia
}

Received 28.11.2014, received in revised form 04.01.2015, accepted 09.02.2015

\begin{abstract}
International migration in modern society is a substantially significant phenomenon in terms of size, socio-economic and political consequences for countries and regions. Migration policy is defined as a set of measures taken by the state and society for the regulation of migration, adaptation and integration of immigrants to the benefit of the state and society. One of the main objectives of the migration policy is to regulate migration flows in order to stimulate economic development, taking into account demographic situation and labor market development.

The following factors stimulate global migration flows: demographic indicators, volume of labor resources, high unemployment rates, unfavorable sanitary and epidemiological conditions, chronic poverty, ethnic conflicts and local wars, as well as awareness of the poorest countries of their plights compared to the situation in Western countries.

Migration Legislation, in the recent history of the Russian Federation, purposefully started to form in 1992. It works as a body of law regulating migration processes in society, including relations connected with the implementation of rights of migrants and ensuring the implementation of migration policies by the state bodies. In order to adjust and control migration flows Russia has taken the integration type of the policy.
\end{abstract}

Keywords: migration policy, natural population growth, integration policies, labor migration, internal migration, enclave.

Research area: politology.

International migration in modern society is a substantially significant phenomenon in terms of size, socio-economic and political consequences for countries and regions. In my article, I want to appeal to the trends of migration processes at the present time and to envisage prospects of migration policy in general.

The authors of the training manuals "Fundamentals of Migration Policy", developed by the Federal Migration Service of Russia and the Russian Academy of Public Administration under the President of the Russian Federation, give the following definition of the term "migration policy": a set of measures taken by the State and society for the regulation of migration, adaptation and integration of immigrants to the benefit of the state and society.

One of the main objectives of the migration policy of any country is to regulate migration flows in order to stimulate economic development.

(C) Siberian Federal University. All rights reserved

* Corresponding author E-mail address: tsksib@mail.ru 
Given that, this task is being implemented with the reference to demographic and labor market development. On the global scale, it is demographic indicators and the volume of the labor force, which work as incentives for migration movements.

The predominant direction of modern migration flows are movements of people from the poorest developing countries, where the population density is quite high and economic performance is low, to the developed countries with low or negative demographics, but with a high standard of living.

For example, depopulation is revealed in countries with high socio-economic indicators: in Germany recorded negative growth $(-0.1 \%)$, zero growth - in Italy, very low natural growth - in the United Kingdom (0.1\%), Japan (0.2 \%), Canada $(0.3 \%)$, France $(0.4 \%)$, USA (0.5\%).

In contrast, the population of developing countries is growing rapidly: in Palestine, it increases by $3.7 \%$ per year, Yemen - by $3.3 \%$, in Congo - by $3.1 \%$, Burkina Faso - by $3.0 \%$, Ethiopia - by $2.9 \%$.

Birth rates also differ incomparably. Total birthrate rate in Niger is 7.5 children per woman, in Yemen - 7.2, Congo - 6.3, Afghanistan - 6.0, Palestine - 5.9, while the EU is just over 1.3 and in the US -2.13 .

The demographic problem, including Russia, also remains extremely acute. According to the Federal State Statistics Service, from 1990 to 2012, there was a natural population decline; in 2012, a growth was recorded at zero and in 2013, the natural growth rate was 0.3. Definitely, measures taken recently by the state have had their effect: the maternity capital, the growth of children's allowances, the total welfare of Russian citizens and the level of migration.

However, according to Rosstat (the Statistics Bureau of Russia), up to 2030 natural growth is going to be negative. In other words according to the worst forecast there is going to be 8 newly born persons per 16.8 deceased. And if the situation goes a better way, than the best option forecast is going to be 10.8 births per 11.2 deceased.

Thus, the population losses are possible and necessary, according to experts, to compensate by regulated and planned processes of migration exchange.

It should be noted that the scale of migration in the world tends to permanently increase - it involves more and more people.

In recent years, the global economy has really clearly shaped two opposite poles - the rich North and the poor South, which differ not only by demographic parameters, but also by social and economic conditions, which traditionally generate international migration.

The existence of economic "divide" between developed, developing and poor countries, as well as pay inequity, has become self-evident.

In addition, numbers hide such complex and important issues for developing countries, as hunger, high unemployment, unfavorable sanitary and epidemiological conditions, chronic poverty, ethnic conflicts and local wars.

All these factors contribute to the everincreasing scale of global migration.

However, it is not quite correct to explain the process of migration intensity only by such objective reasons as the demographic and socio-economic differentiation. According to experts who examine migration issues, the intensity of migration processes has recently become influenced by subjective components, which are peculiar to individual societies and communities.

First of all, this is the awareness by the broad masses of people in the poorest countries of their plights as compared to Westerners. Professor N.M. Rimashevskaya stipulates: "the poor become poor not only due to their income, but 
due to the realization of the fact that they do not have something that others have". Globalization has destroyed the isolation of local communities, increased the flow of information on the quality of life in the West, has created envy and the desire of "the poor" to at least minimally approach to a similar level of consumption, to stimulate migration in economically developed countries. Potential migrants through the channels of their kinship, and the mass media receive information on socio-economic opportunities in developed countries.

Thus, in the context of the world economy globalization two main groups of migration factors have clearly took their shape. The first group is comprised of objective factors of the socioeconomic and demographic type: unemployment, poverty, overcrowding. The second group are subjective factors: awareness of the situation of hopelessness and life prospects in the country of previous residence, a desire to improve living standards and income.

In summary, it is worth of note that migration policy, affecting all levels of human life in society is always a concern for the state. If the state indifferently gazes at mass movements of people, does not establish proper border control and does not render assistance to those who came from abroad, does not help them to get established and adopted to a new place or does not take measures to reduce the departure of its citizens abroad, such a state prefers spontaneous selfregulation of these processes. Such a shortsighted governmental policy cannot lead to improved living standards.

There is another, more populist view of migration processes. An English scholar Salt believes that international migration in the context of globalization is an organized branched type of international business, which has a huge budget; it manipulates hundreds of thousands of jobs and people around the world and is managed by a network of organizations and institutions, which have vested interest in this business.

Governments that stimulate the migration of their citizens abroad, are usually driven by pragmatism, because this way helps them to at least partially ease the socio-economic and demographic "tension" in society, without investing special funds in social programs, employment policy, education, health, and social services.

Known facts from the history of some countries clearly demonstrate that active resettlement of migrants sometimes was followed by economic expansion, and then annexation of neighboring territories as a result of political or military intervention. For example, territorial conquests in North America by the British, Dutch and French or the acquisition of Texas territory from Mexico. At first glance, in the modern world such a scheme of events looks, at least, outdated and hard to implement. But in the era of globalization, there are quite differentmechanisms of influence - economic and financial levers, and the role of migration and migrants in the global geopolitical projects is still quite important.

In this regard, the situation is most evident in China, experiencing in recent years, rapid economic growth. It operates the concept of a single nation, which is an integral part of foreign policy. The Government makes a clear distinction between the state and national interests: the first affect the sovereignty of China and the second a single nation with the area of settlement much larger than that within the country's borders.

Undoubtedly, the Chinese are the largest community in the world. In some countries in Southeast Asia, the Chinese actually have developed a mechanism of economic expansion through a change in the ethnic composition of the population. Closed and hierarchical Chinese communities have allowed Chinese people to preserve their ethnic identity. The Chinese 
are not only not disappeared among the other ethnic groups, but also created a parallel world of business, most of which at first stayed in the shadows, but eventually took de facto control of the economy of Singapore, Indonesia, Thailand and the Philippines.

Chinese business in the Far East also successfully besieges Russia in trade, production of food and consumer goods, construction. This contributes to the outflow of the Russian population of these regions and the influx of Chinese into it. In connection with the entry of Russia into the WTO, these processes are likely to be intensified as the charter of the organization is based on the principle of giving national trade regime to entrepreneurs from WTO member countries.

This is a typical feature of migration policies in the Asia-Pacific region, which are based on the implementation of the task of increasing competitiveness on the world market and the export of labor, becoming a source of hard currency for the home country.

If we turn to the experience of migration policy in Europe and the US, we see a different model. Thus, the countries with the classical model of immigration are believed to be the United States, Canada, Australia and New Zealand, which were created because of migration. Europe for many centuries has been a migration donor for these countries.

A different model is typical for European countries - France, Germany, the UK, and Spain. Until the end of World War II and the postwar period, as already mentioned earlier, the European migration system was a donor. In the second half of the last century, Europe began to experience a new stage in the history of migration. This was driven by such factors as the collapse of the political system in the former socialist camp, the expansion of the European Union, as well as the growth of illegal immigration from Asia and
Africa. It should be noted that the European states are faced with a number of global socio-economic problems, among which, on the one hand, low birth rates and aging population and shortage of labor, on the other hand, the consequences of enlargement of the European Union and the financial and economic crisis.

Now we shall turn to the trends of the Russian migration model.

The formation of Russian migration policy began in the 16th century. The Russian Empire was a multinational state in which migration always played an important role. The territory of Russia was constantly expanding by addition of new lands. As a result, it has become one of the largest countries in the world. In order to consolidate and develop new areas there was a need for "infusions" of human resources, which were always insufficient. Settling of the territory was carried out by both internal migration and attracting foreign citizens.

So, in 1652, a decree was issued according to which there was allocation of special areas outside of Moscow for German settlement, where immigrants from Western Europe settled, who were allowed to live "in their own way". Only those foreigners who took Russian religion could stay in the center of Moscow. Thus, we see the initial stages of formation of the legal institution of a temporary resident foreigner.

In 1861, the settlement of the Far East started and "Regulations for the settlement of Russians and foreigners in the Amur and Primorskaya regions" were published. It was a period of internal resettlement policy development.

In the pre-revolutionary period comes the understanding that successful solutions of migration problems require direct assistance of the state in the preparation, relocation and settlement of migrants. The presence of such assistance from the state is an important incentive and control over the volume of migration. 
In the aftermath of the October Revolution to the present time there has been a huge amount of historical events that influenced the development of the migration policy of our state in the form in which we now can observe it.

Given the territorial extent, different climatic and socio-economic conditions of the regions in our country there is a significant regional differentiation of migratory factors.

There are subjects of the Russian Federation that do not need an influx of new people and that, on the contrary, would like to solve the problem of unemployment by releasing economically active, but remaining outside the employment, citizens to other regions. Yet there are, on the other hand, unused lands, which need a fresh spark of life to be taken to them. Therefore, the federal migration policy, points out common methods and approaches to their development and implementation, provide freedom of regional and local authorities in the development of specific measures.

Russian regions, in terms of migration situation and demographic development, are very different from each other. The Far East is experiencing a catastrophic outflow of population, with each year relative and absolute number of its inhabitants is being reduced.

However, on the global scale, Russia in the $21^{\text {st }}$ century has become a country that is ranked third in the world in the reception of migrants after the United States and Germany.

By the early 21st century, Russia came up with a profound crisis of migration, which was a natural consequence of the collapse of the USSR, a severe economic depression, protracted armed conflict and the collapse of many familiar landmarks of life and acute demographic problems.

Along with the stabilization of the overall situation, overcoming the economic depression, increasing economic growth, stress factors generated by them and forced migration tend to disappear. Migration processes become again coordinated by demand for labor, difference in living standards and wages.

Experts studying the migration process, identified several types of policies:

- policy of multiculturalism;

- policy of segregation or restriction of places of residence of migrants;

- policy of tightening mode selection or selection of migrants;

- policy of isolation - when the host society is fenced off from immigrants by severely restricting migration;

- and integration policies.

A little more focus on integration policy, due to the fact that Russia in the last decade has taken this type of policy formation and control of migration flows.

The concept of integration policy is quite heavy. Today integration policy includes the management and control of migration flows, the creation of mechanisms and selective activity on the integration of immigrants into society, work with immigrants and people on the formation of tolerant attitudes. Such a policy was established in Belgium, Denmark, Germany, France, Sweden and some other European countries. Under this policy, government programs accept integration of migrants, their admission criteria are developed, trained professionals are organized for immigrant courses in the national language, special public authorities are formed, for example, in Germany - The Ministry for Integration.

Russian integration policy is in its infancy. In September 2010, in the structure of the Federal Migration Service was formed a Department for integration facilitation. Its work is aimed at the development and implementation of such measures as promoting the integration of migrants into Russian society, promoting the principles 
of tolerance and banning of discrimination and xenophobia.

Office of the Federal Migration Service of the Krasnoyarsk Kray is conducting its systematic work to promote the integration of migrants and to carry out the tasks set by the President, the Government of the Russian Federation and the Russian Federal Migration Service.

Active development of the industrialeconomic complex of the Krasnoyarsk Kray is one of the incentives for migrants in our region, as was evidenced by the following statistics.

During 10 months of 2014 the number of foreign nationals who registered and received a temporary permit, compared to the same period last year increased by $4.7 \%$ (or plus 7471) and amounted to 167 thousand people.

As donors of labor, of course, one would like to see countries, which are close to us culturally. For example, the countries of Eastern Europe. But hopes for this are illusory. Russia can rely mainly on South-East and South Asia. The main donor of Russian migrants is Central Asia, which provides nearly $70 \%$ of the influx of migrants. At the same time, in general these migrants have a low cultural and educational level.

As a result the influx of migrants changes the ethnic composition of the population, forms national enclaves. This leads to spontaneous and uncontrolled growth of ethnic groups and, as a consequence, to deterioration of the crime situation. However, conflicts on ethnic and religious grounds in the Krasnoyarsk Kray have not been registered, compared to regions of Western Russia. This result was achieved in part due to the interaction system created by public authorities, educational institutions and public organizations in the adaptation and integration of migrants.

Assessment of the situation in the Krasnoyarsk Kray leads to the conclusion that the migration situation is under the control of the Office and other law enforcement agencies. Interethnic relations in the region remain stable and helpful enough.

It should be noted that the elimination of the prerequisites of extremism and ethnic conflict depends not only on preventive measures, but also on the social and economic organization of society, the development of social institutions that can meet the demands of indigenous peoples and visitors.

Conventionally, this work can be divided into two areas: firstly, it is working meetings with formal and informal representatives of national associations, religious organizations and groups of migrants. This form of work allows to quickly respond to various situations that arise among migrants, including monitoring of emerging adverse events associated with xenophobia and extremism. For example, in 2014 the staff of the migration service of the Krasnoyarsk Kray held 48 meetings with representatives of national associations.

The second line of activity is interagency cooperation.

The result of this interaction was a signed cooperation agreement with the Krasnoyarsk regional department of the Russian public organization "Association of Lawyers of Russia" on free legal counseling of migrants. Students of Law Institute of Siberian Federal University are actively involved into this process.

Also, the Office communicates with only one at the moment private educational institution "School of Foreign Language", which teaches Russian to foreign nationals at free of charge courses. Since 2011, about 400 workers, including children, havereceived theirgraduation certificate. Knowledge of the Russian Language - the state language of the Russian Federation is the most important stage of adaptation of foreign citizens. In most cases, poor knowledge of the Russian language is the main reason for getting migrants 
in situations of violation of the legislation of the Russian Federation. Therefore, the work on opening of cultural and language courses lies in the concept of migration policy.

The Department within its competence on a regular basis takes part in meetings of the committees and "round tables", academic conferences on inter-ethnic tolerance. In addition, the Office active uses its Community Advisory Board and the Council of national associations. On a regular basis at the Council meetings it discusses issues related to the activities to promote the adaptation and integration of migrants.

Development of interagency cooperation on adaptation of migrants is supported by the annual discussion platform "Adaptation of migrants factor of a civilized society", which was jointly organized by the Office of the Migration Service of the Krasnoyarsk Kray and Siberian Federal University. This platform has been used within this conference for the third year in a row.

Representatives of the executive authorities of the Krasnoyarsk Kray and local governments, non-governmental organizations, national associations, educational and scientific institutions, cultural institutions, as well as other commercial and non-profit organizations are invited for the meeting.

The main purpose of the site is to attract public attention, the authorities and civil society organizations to the problem of adaptation of migrants. Tomorrow is going to be another discussion forum on the theme "Adaptation of migrants is a priority issue of stability of interethnic relations in the Krasnoyarsk Kray", which will discuss the issue of opening a Center for Adaptation of migrants in the city of Krasnoyarsk, as well as knowledge of the Russian language by foreign citizens.

The most probable future projections will be associated only with an increase in migration flows in Russia in general and in our region in particular. In this connection, the improvement of migration legislation is a priority.

Migration Legislation, in the recent history of the Russian Federation, started to purposefully form in 1992. It acts as a body of law regulating migration processes in society, including the relations connected with the implementation of rights ofmigrants and ensuring the implementation of migration policy by state bodies.

Currently, Russia as the host State, in shaping immigration policy puts forward a solution to the issue of legalization of migrant workers, primarily through the adoption of clear immigration law, based on the real needs of the labor market. If migrants want to become citizens of the Russian Federation, they are to show their desire to take culture of Russia, respect the Constitution and the law, need effective mechanisms of social and economic integration. In particular, one of the steps to implement the policy of integration of migrants into the host society are changes made to the Federal Law № 115 "On the Legal Status of Foreign Citizens in the Russian Federation", which state that since January 1, 2015 a foreign citizen is supposed to produce (present) a national document confirming his (her) knowledge of the Russian language and culture and basic rights of the Russian Federation when applying for a permit for temporary residence, residency and work permits and patents.

Given the complexity of the migration processes in Russia, the regulation of migration law belongs to the category of complex national problems that require consideration of the entire sum of factors influencing the situation. And we (I mean, the authorities, academic community, public institutions and every citizen as a single entity), can influence the migration policy of our country, developing it. After all, in today's world migration issues are not only the state's prerogative. 
In conclusion, I wish to note that the guidelines of the Concept of State Migration Policy of the Russian Federation are:

- overcome labor shortages;

- maintain the growth of employment in the economy by increasing the territorial mobility of the national labor force;

- volume regulation to attract foreign labor;
- increase in migration growth to stabilize and gradually increasing of the population.

Therefore, the Department of the Federal Migration Service of the Krasnoyarsk Kray by following the guidelines of migration policy works for the development of our state as a civilized and legal country.

\section{References}

1. Osnovymigratsionnoypolitiki:uchebno-metodicheskoyeposobiye(Fundamentals ofmigration policy: a teaching aid) / Pod obshchey redaktsiyey Bartsitsa I.N., Yegorova V.K., Romodanovskiy K.O., Tyurkina M.L. M.: 2010. 478 p.

2. Tsapenko I. Razvityye strany: integratsionnaya politika $v$ otnoshenii migrantov (Developed countries: integration policies towards migrants) //MEMO. 2008. № 3.

3. Tyurkin M.L. Migratsionnaya politika Rossiyskoy Federatsii. Opyt i perspektivy razvitiya. (Migration Policy of the Russian Federation. Experience and prospects of development) M., 2009. 20p.

4. Zayonchkovskaya Zh.A. Razvitiye vneshnikh migratsionnykh svyazey Rossii (Development of external migration ties in Russia)// Sotsiologicheskiy zhurnal, 1995. № 1. Pp. 29-44.

5. Rimashevskaya N.M., Galetskiy V.F, Ovsyannikov A.A. i dr. // Naseleniye i globalizatsiya (Population and globalization). M.: Nauka, 2002. P. 24.

6. Ryazantsev S. Migratsionnyye trendy $i$ mezhdunarodnaya bezopasnost' (Migration trends and international security) // Zhurnal teorii mezhdunarodnykh otnosheniy i mirovoy politiki «Mezhdunarodnyye protsessy». T. 11, № 3-4, 2013.

7. Federal'nyy zakon ot 25.07.2002 g. № 115-FZ “O pravovom polozhenii inostrannykh grazhdan v Rossiyskoy Federatsii” (Federal Law of 25.07.2002 № 115-FZ “On the Legal Status of Foreign Citizens in the Russian Federation.).

8. Federal'nyy zakon ot 20.04.2014 g. № 74-FZ “O vnesenii izmeneniy v Federal'nyy zakon "O pravovom polozhenii inostrannykh grazhdan v Rossiyskoy Federatsii” (Federal Law of 20.04.2014, № 74-FZ "On Amendments to the Federal Law” On Legal Status of Foreign Citizens in the Russian Federation.).

9. Federal'nyy zakon ot 18.07.2006 g. № 109-FZ "O migratsionnom uchete inostrannykh grazhdan i lits bez grazhdanstva $v$ Rossiyskoy Federatsii” (Federal Law of 18.07.2006, № 109-FZ “On Migration Registration of Foreign Citizens and Stateless Persons in the Russian Federation").

10. Ukaz Prezidenta Rossiyskoy Federatsii ot 09.10.2007 g. № 1351 "Ob utverzhdenii Kontseptsii demograficheskoy politiki Rossiyskoy Federatsii na period do 2025 goda" (Decree of the President of the Russian Federation of 09.10.2007, № 1351 "On approval of the Concept of Demographic Policy of the Russian Federation until 2025”).

11. Kontseptsiya gosudarstvennoy migratsionnoy politiki na period do 2025 goda, podpisannaya Prezidentom Rossiyskoy Federatsii v 2012 godu (The concept of the state migration policy for the period up to 2025, signed by the President of the Russian Federation in 2012). 


\title{
Миграционный вопрос на современном этапе: \\ опыт и перспективы
}

\author{
М.А Юскова, И.Н. Потемкин \\ УФМС России по Красноярскому краю \\ Россия, 660000, Красноярск
}

\begin{abstract}
Международная миграция в современном обществе является довольно значимым явлением c точки зрения масштабов, сочиально-экономических и политических последствий для стран и регионов. Миграционная политика определяется как комплекс мер, принимаемых в государстве и обществе для регулирования переселений, адаптации и интеграции переселениев в интересах этого государства и общества. Одной из основных задач миграционной политики является регулирование миграционных потоков с иелью стимулирования экономического развития страны с учетом демографической ситуации и развития рынка труда. К факторам, стимулирующим мировую мигращию, относятся показатели демографии, объем трудовых ресурсов, высокая безработица, неблагополучная санитарно-эпидемиологическая обстановка, хроническая бедность, межнациональные конфликты и локальные войны, а также осознание населением беднейших стран своего тяжелого положения по сравнению с жителями стран 3anada.

Миграционное законодательство в новейшей истории Российской Федерации иеленаправленно формируется с 1992 года и представляет собой совокупность норм права, регулируюших миграчионные прочессы в обществе, включая отношения, связанные с реализачией прав мигрантов и обеспечением реализации государственными органами миграционной политики. Россия для формирования и контроля миграџионных потоков приняла интеграционный тип политики.
\end{abstract}

Ключевые слова: миграционная политика, естественный прирост населения, политика интеграции, мигрант, трудовая миграция, внутренняя миграчия, анклав.

Научная спечиальность: 23.00.00 - политология. 